\title{
Effects of an acute exacerbation on nutritional and metabolic profile of patients with COPD
}

\author{
M.A.P. Vermeeren*, A.M.W.J. Schols', E.F.M. Wouters ${ }^{+}$
}

\begin{abstract}
Effects of an acute exacerbation on nutritional and metabolic profile of patients with COPD. M.A.P. Vermeeren, A.M.W.J. Schols, E.F.M. Wouters. CERS Journals Ltd 1997. ABSTRACT: In this study, we investigated the influence of an acute disease exacerbation on the nutritional and metabolic status of patients with chronic obstructive pulmonary disease (COPD).

The study group consisted of 23 patients acutely admitted to the hospital for standardized medical treatment. Dietary intake (dietary records and diet history), resting energy expenditure (ventilated hood), body composition (bioelectrical impedance spectroscopy) and disease symptoms (visual analogue scale) were assessed on admission, daily throughout the hospitalization period, at discharge and 3 months thereafter in stable clinical condition.

Dietary intake, since aggravation of disease symptoms, prior to admission, $(5,640 \pm 2,671 \mathrm{~kJ})$ was significantly lower than habitual intake $(7,863 \pm 2,005 \mathrm{~kJ})$. The balance between dietary intake with measured resting energy expenditure and estimated diet-induced thermogenesis was severely impaired during the first 3 days of hospitalization, stabilizing thereafter to $145 \pm 24 \%$ at discharge. Resting energy expenditure decreased from $6,812 \pm 900 \mathrm{~kJ}(123 \pm 11 \%)$ on admission to $6,196 \pm 795$ kJ $(113 \pm 14 \%)$ at discharge $(\mathbf{p}<0.001)$. During treatment, no significant shift in water compartments, fat-free mass and body weight was seen. Follow-up data were obtained from 10 out of 23 patients. Three months after admission, dietary intake was not significantly different from usual dietary intake $(8,512 \pm 2,290$ and $8,415 \pm 2,600$ $\mathrm{kJ}$, respectively), resting energy expenditure was similar to the value at discharge, and a significant body weight gain was seen.

We conclude that an acute exacerbation of chronic obstructive pulmonary disease is accompanied by an impaired energy balance due to a decreased dietary intake and an increased resting energy expenditure.

Eur Respir J 1997; 10: 2264-2269.
\end{abstract}

Depts of *Dietetics and +Pulmonology, University Hospital Maastricht, The Netherlands

Correspondence: A.M.W.J. Schols

Dept of Pulmonology

Maastricht University

P.O. Box 5800

6202 AZ Maastricht

The Netherlands

Keywords: Metabolism

nutrition

obstructive lung disease

Received: November 71996

Accepted after revision June 11997
Tissue depletion frequently occurs in patients with chronic obstructive pulmonary disease (COPD). Reported (prevalence) rates range from $20 \%$ in clinically stable out-patients [1] up to $50 \%$ in patients with acute respiratory failure [2]. Weight loss and, in particular, loss of fat-free mass (FFM) have been shown to adversely influence functional performance [3, 4] and survival [5], independently of the compromised lung function. Wasting of FFM is related to weakening of respiratory [3] and peripheral skeletal muscles [1] and to an impaired exercise performance [4]. Dysfunction of the respiratory muscles is furthermore related to the patient's sensation of dyspnoea [6].

Weight loss results from an imbalance between dietary intake and energy expenditure. In the majority of COPD patients, weight loss appears to develop gradually, while they are in an otherwise stable clinical condition. Previous studies using diet histories found a normal to elevated dietary intake in COPD patients when compared to normal values [7, 8]. A within-group comparison, however, showed a significantly lower dietary intake in weight-losing than in weight-stable patients, both in absolute terms and when expressed as percentage of measured resting energy expenditure (REE) [8]. Several studies have shown an increased REE, in addition to a relatively decreased dietary intake, in clinically stable COPD patients, the cause of which is unclear [9, 10].

Retrospective data suggest that, in a sub-group of patients, weight loss follows a stepwise pattern related to acute disease exacerbations. However, limited data are available on dietary intake and energy metabolism in COPD during an acute disease exacerbation. The aim of the present study was, therefore, to investigate the effect of an acute exacerbation on the nutritional and metabolic profile of patients with COPD.

\section{Methods}

\section{Patients}

Patients admitted to the respiratory unit of the University Hospital Maastricht with an acute exacerbation of COPD were considered for inclusion in the study. COPD was defined according to the criteria of the American Thoracic Society [11]. All patients were current or exsmokers. None had evidence of significant reversibility ( $>15 \%$ of predicted baseline) of air flow obstruction 
after $500 \mu \mathrm{g}$ of terbutaline inhalation. An acute exacerbation was defined as a recent increase in dyspnoea, cough and sputum production of sufficient severity to warrant hospital admission. Patients suffering from concomitant diseases such as diabetes mellitus, lung carcinoma, thyroid and cardiovascular disease, were excluded from the study. In-hospital treatment consisted of parenteral corticosteroids and theophylline in addition to nebulized beta-agonists and ipratropium bromide and broadspectrum antibiotic therapy, in case of bacterial infection confirmed by clinical data and sputum culture. The daily $500 \mathrm{~mL}$ infusion solution contained $5 \%$ glucose which is equivalent to $419 \mathrm{~kJ} \cdot \mathrm{day}^{-1}$. This value is incorporated in the calculations of the energy balance during hospitalization, but not in the calculations of "spontaneous" dietary intake.

Measurements were performed during the hospitalization period, and all patients were invited for a follow-up consultation 3 months after discharge when they were in stable clinical condition. The study was approved by the medical Ethics Committee of the University Hospital of Maastricht. Informed consent was obtained from all subjects.

\section{Dietary intake}

Habitual dietary intake, dietary intake prior to admission since aggravation of dyspnoea and other disease symptoms, as well as dietary intake during the followup consultation were evaluated using the diet history method with cross-check [12]. All interviews were performed by the same trained dietician. During hospitalization, dietary intake was registered daily using dietary records and an automated food distribution system. Patients were not receiving nutritional support during their hospitalization, but they had the opportunity to choose their menus. Food composition data were coded for computer energy and nutrient analysis. The database was derived from the Dutch food composition tables [13].

\section{Resting energy expenditure}

REE was measured the day after admission, at discharge and during the out-patient follow-up by indirect calorimetry using a ventilated hood system (Oxycon- $\beta$, Mijnhardt, Bunnik, The Netherlands) [14]. Standardized measurements of volume of oxygen utilization $\left(V^{\prime} \mathrm{O}_{2}\right)$ and carbon dioxide output $\left(V^{\prime} \mathrm{CO}_{2}\right)$ were performed in the early morning in the fasting state (between 08.30 and $09.30 \mathrm{~h}$ ) approximately $3 \mathrm{~h}$ after the patients had received their regular medication. If patients were on oxygen therapy, the oxygen was withdrawn temporarily $30 \mathrm{~min}$ prior to the measurement and, in these patients, oxygen saturation was measured continuously during the measurement. The patients did not experience a worsening of dyspnoea after withdrawal of the oxygen. In a subgroup of nine patients, REE was measured daily to assess the variability and course of REE during hospitalization.

\section{Diet-induced thermogenesis}

Diet-induced thermogenesis (DIT) was estimated as $10 \%$ of dietary intake.

\section{Body composition}

During hospitalization, fasting body weight was assessed daily using a digital weighing chair. Body composition was measured the day after admission, at discharge and during the out-patient follow-up by bioelectrical impedance spectroscopy (Xitron 4000B; Xitron Technologies Inc., San Diego, CA, USA) [15]. The principle of this method is based on the conductivity of an electrical sinusoidal alternating current through body fluids. Conductivity is higher in the FFM, which contains all body fluids and electrolytes, than in fat mass. The resistance of the body can be measured at a spectrum of frequencies (ranging 5-500 kHz). At low frequency $(<50$ $\mathrm{kHz}$ ), the conductivity is mainly through the extracellular part, while at higher frequency conductivity takes place through total body water. Resistance of intracellular and extracellular water was measured by extrapolation of the measured resistance and reactance according to the Cole-Cole model [16].

\section{Disease symptoms}

Disease symptoms were scored using a visual analogue scale (VAS) on admission, on day 5 of hospitalization, at discharge and during the follow-up consultation. The following symptoms were evaluated: loss of appetite; dyspnoea at rest and while eating; early satiety; nausea; obstipation; dry mouth; problems with chewing and swallowing; diarrhoea; flatulence; nervousness; fatigue; and disturbed sleeping.

\section{Statistical analysis}

Groups were compared by analysis of variance or by the Mann-Whitney U-test, where appropriate. The ChiSquared test was used to compare categorical variables. Changes within the patient were compared using a paired t-test. Results are presented as mean \pm SD unless stated otherwise. A p-value of less than 0.05 was considered statistically significant. The statistical analyses were performed using the Statistical Products and Service Solutions (SPSS; Chicago, IL, USA) for Windows package [17].

\section{Results}

Twenty three consecutive patients were studied. Characteristics of the total group, as well as the subgroup of 10 patients that participated in the follow-up consultation, are given in table 1 . Mean forced expiratory volume in one second (FEV1) amounted to $37 \pm 12 \%$ of predicted. Mean body mass index (BMI) was $23 \mathrm{~kg} \cdot \mathrm{m}^{-2}$, ranging from $16-29 \mathrm{~kg} \cdot \mathrm{m}^{-2}$. Based on a BMI $\leq 21 \mathrm{~kg} \cdot \mathrm{m}^{-2}$, eight patients were underweight. Five patients were admitted with acute respiratory failure (arterial oxygen tension $\left(\mathrm{Pa}, \mathrm{O}_{2}\right)<7.3 \mathrm{kPa}$ and/or arterial carbon dioxide tension $\left.\left(\mathrm{Pa}, \mathrm{CO}_{2}\right)>6.0 \mathrm{kPa}\right)$. Fifteen patients were treated with antibiotics.

\section{Dietary intake}

Dietary intake in the period prior to admission amounted to $5,640 \pm 2,671 \mathrm{~kJ} \cdot \mathrm{day}^{-1}$ and was significantly 
Table 1. - Baseline characteristics of the total study group and the subgroup that participated in the followup study

\begin{tabular}{lcc}
\hline & $\begin{array}{c}\text { Total group } \\
\mathrm{n}=23\end{array}$ & $\begin{array}{c}\text { Follow-up } \\
\mathrm{n}=10\end{array}$ \\
\hline Age yrs & $63 \pm 8$ & $65 \pm 9$ \\
$\mathrm{Sex} \mathrm{M/F}$ & $12 / 11$ & $7 / 2$ \\
$\mathrm{IVC} \mathrm{\%}$ & $70 \pm 22$ & $81 \pm 23$ \\
$\mathrm{FEV} 1 \%$ & $37 \pm 12$ & $41 \pm 9$ \\
$\mathrm{~Pa}_{\mathrm{a}} \mathrm{\textrm {O } _ { 2 }} \mathrm{kPa}$ & $8.8 \pm 2.3$ & $9.9 \pm 2.9$ \\
$\mathrm{~Pa}, \mathrm{CO}_{2} \mathrm{kPa}$ & $5.0 \pm 0.9$ & $4.6 \pm 0.7$ \\
$\mathrm{Habitual} \mathrm{weight} \mathrm{kg}$ & $63.5 \pm 12.0$ & $67.2 \pm 12.2$ \\
Weight on & & \\
$\quad$ admission kg & $63.4 \pm 11.9$ & $67.5 \pm 12.2$ \\
BMI kg·m-2 & $23.0 \pm 3.2$ & $24.4 \pm 2.5$ \\
\hline
\end{tabular}

Values are mean \pm SD, or absolute number for sex. None of the differences between the total group and the follow-up group were significant. IVC: inspiratory vital capacity; FEV1: forced expiratory volume in one second; $P \mathrm{a}_{1} \mathrm{O}_{2}$ : arterial oxygen tension; $\mathrm{Pa}_{\mathrm{a}} \mathrm{CO}_{2}$ : arterial carbon dioxide tension; $\mathrm{BMI}$ : body mass index.

$(\mathrm{p}<0.001)$ lower than habitual dietary intake $(7,863 \pm$ $\left.2,005 \mathrm{~kJ} \cdot \mathrm{day}^{-1}\right)$. Dietary intake increased substantially during hospitalization from $4,467 \pm 2,294 \mathrm{~kJ} \cdot$ day $^{-1}$ at day 1 to $9,048 \pm 2,491 \mathrm{~kJ} \cdot \mathrm{day}^{-1}$ at day 4 , after which it remained stable. Dietary intake at discharge was significantly higher than habitual dietary intake $(9,545 \pm 2,688$ $\mathrm{kJ} \cdot \mathrm{day}^{-1}$ and 7,863 $\pm 2,005 \mathrm{~kJ} \cdot$ day $^{-1}$, respectively, $\mathrm{p}<0.01$ ). Protein, fat and carbohydrate intake in absolute terms and expressed as a percentage of total energy intake is shown in table 2. Protein intake was low prior to hospitalization as well as during approximately the first 3 days of hospitalization, gradually increasing thereafter. Fat intake was low prior to and on admission, but increased thereafter by a greater proportion than carbohydrate intake. Figure 1a shows the daily dietary intake pattern of the subgroup of nine patients in which resting energy expenditure was also measured daily. This figure showed a similar pattern as described for the total group.

\section{Resting energy expenditure}

REE amounted to $6,812 \pm 900 \mathrm{~kJ} \cdot$ day $^{-1}$ on admission and decreased significantly $(\mathrm{p}<0.001)$ to $6,196 \pm 795 \mathrm{~kJ} \cdot$ day $^{-1}$
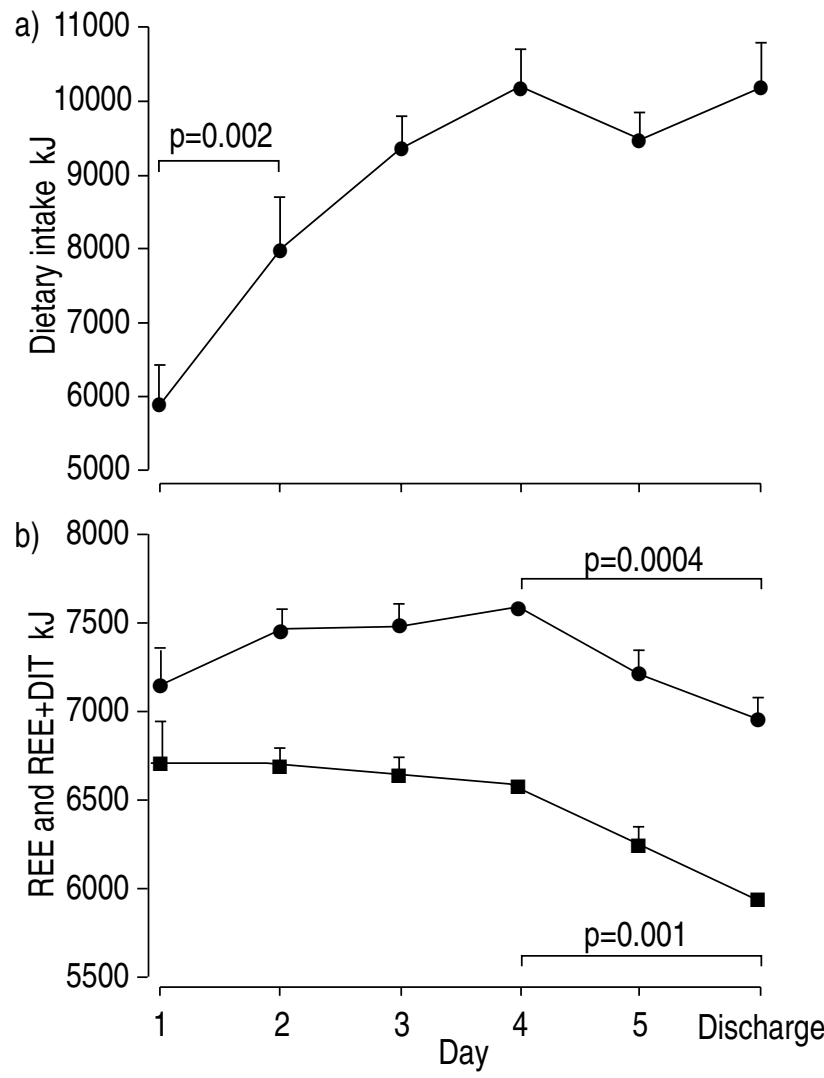

Fig. 1. - a) Daily course of dietary intake; b) daily course of measured resting energy expenditure (REE) ( $\mathbf{\square})$, and REE+diet-induced thermogenesis (DIT) $(\bullet)$, during hospitalization in nine patients with chronic obstructive pulmonary disease. Results are mean \pm SEM.

at discharge. In the patients in whom resting energy expenditure was measured daily, REE remained elevated during the first 4 days after which it decreased until discharge (fig. 1b). Changes in REE were not related to changes in body temperature. Respiratory quotient increased significantly $(\mathrm{p}<0.001)$ from $0.77 \pm 0.05$ on admission to $0.85 \pm 0.01$ at discharge. Measured REE was also compared to the commonly used prediction formulas by HARRIS and BENEDICT [18]. REE was $123 \pm 11 \%$ the day after admission and $113 \pm 14 \%$ at discharge $(\mathrm{p}<$ $0.001)$. On basis of an REE $>110 \%$ pred at discharge,

Table 2. - Macronutrient intake

\begin{tabular}{|c|c|c|c|c|c|c|c|c|}
\hline & \multicolumn{2}{|c|}{ Diet history } & \multicolumn{6}{|c|}{ Dietary records } \\
\hline & Habitual & Pre-admission & Day 1 & Day 2 & Day 3 & Day 4 & Day 5 & Discharge \\
\hline Protein $\mathrm{g}$ & $\begin{array}{c}64.3 \\
( \pm 19.4)\end{array}$ & $\begin{array}{l}49.2 \S \\
( \pm 23)\end{array}$ & $\begin{array}{c}37.4 \\
( \pm 20.6)\end{array}$ & $\begin{array}{c}61 \\
( \pm 25.4)\end{array}$ & $\begin{array}{c}69.7 \\
( \pm 27.9)\end{array}$ & $\begin{array}{c}74.4 \\
( \pm 24.2)\end{array}$ & $\begin{array}{l}73.7 \# \# \\
( \pm 24)\end{array}$ & $\begin{array}{c}81 \ddagger \\
( \pm 27.1)\end{array}$ \\
\hline Protein $\mathrm{g} \cdot \mathrm{kg}^{-1}$ & $\begin{array}{c}1.03 \\
( \pm 0.32)\end{array}$ & $\begin{array}{c}0.78 \S \\
( \pm 0.33)\end{array}$ & $\begin{array}{c}0.59 \\
( \pm 0.33)\end{array}$ & $\begin{array}{c}0.6 \\
( \pm 0.33)\end{array}$ & $\begin{array}{c}0.96 \\
( \pm 0.4)\end{array}$ & $\begin{array}{c}1.12 \\
( \pm 0.53)\end{array}$ & $\begin{array}{c}1.22 \# \# \\
( \pm 0.42)\end{array}$ & $\begin{array}{c}1.32 \ddagger \\
( \pm 0.5)\end{array}$ \\
\hline Protein \% & $\begin{array}{l}14.9 \\
( \pm 3.1)\end{array}$ & $\begin{array}{c}14.1 \\
( \pm 2.2)\end{array}$ & $\begin{array}{c}14.1 \\
( \pm 2.5)\end{array}$ & $\begin{array}{c}14.9 \\
( \pm 3.7)\end{array}$ & $\begin{array}{c}14.1 \\
( \pm 3.2)\end{array}$ & $\begin{array}{l}13.7 \\
( \pm 3)\end{array}$ & $\begin{array}{c}14.2 \\
( \pm 2.9)\end{array}$ & $\begin{array}{c}14.1 \\
( \pm 2.7)\end{array}$ \\
\hline Fat $g$ & $\begin{array}{c}80.6 \\
( \pm 23.5)\end{array}$ & $\begin{array}{c}58.2 \S \\
( \pm 27.7)\end{array}$ & $\begin{array}{c}40.2 \\
( \pm 23.7)\end{array}$ & $\begin{array}{c}67.9 \\
( \pm 38.5)\end{array}$ & $\begin{array}{c}90.4 \\
( \pm 33.2)\end{array}$ & $\begin{array}{c}94.7 \\
( \pm 33.8)\end{array}$ & $\begin{array}{c}89.2^{\# \#} \\
( \pm 27.9)\end{array}$ & $\begin{array}{c}103.5 \ddagger \\
( \pm 32.5)\end{array}$ \\
\hline Fat \% & $\begin{array}{l}40.5 \\
( \pm 10)\end{array}$ & $\begin{array}{c}38.9 \\
( \pm 7.7)\end{array}$ & $\begin{array}{c}32.9 \\
( \pm 10.1)\end{array}$ & $\begin{array}{c}35.7 \\
( \pm 9.2)\end{array}$ & $\begin{array}{c}41.7 \\
( \pm 6.8)\end{array}$ & $\begin{array}{c}38.8 \\
( \pm 6.9)\end{array}$ & $\begin{array}{c}38.2^{\#} \\
( \pm 5.2)\end{array}$ & $\begin{array}{l}40.5 \\
( \pm 6.7)\end{array}$ \\
\hline Carbohydrates g & $\begin{array}{c}217.3 \\
( \pm 74.8)\end{array}$ & $\begin{array}{c}155.7 \S \\
( \pm 91.7)\end{array}$ & $\begin{array}{c}140 \\
( \pm 74.4)\end{array}$ & $\begin{array}{c}204.7 \\
( \pm 83.6)\end{array}$ & $\begin{array}{c}217.8 \\
( \pm 77.6)\end{array}$ & $\begin{array}{c}253.9 \\
( \pm 71.6)\end{array}$ & $\begin{array}{l}251.1^{\# \#} \\
( \pm 84.3)\end{array}$ & $\begin{array}{l}258 \\
( \pm 83)\end{array}$ \\
\hline Carbohydrates \% & $\begin{array}{c}44.1 \\
( \pm 12.1)\end{array}$ & $\begin{array}{c}46 \\
( \pm 9.6)\end{array}$ & $\begin{array}{c}53.1 \\
( \pm 15.0)\end{array}$ & $\begin{array}{c}49.4 \\
( \pm 10.5)\end{array}$ & $\begin{array}{c}44.2 \\
( \pm 8.1)\end{array}$ & $\begin{array}{l}47.5 \\
( \pm 7)\end{array}$ & $\begin{array}{c}47.7 \\
( \pm 6.6)\end{array}$ & $\begin{array}{l}45.4^{\dagger} \\
( \pm 7.5)\end{array}$ \\
\hline
\end{tabular}

Values are means with SD in parenthesis. $\$$ : p $<0.005$ comparison between habitual and pre-admission; \#: $\mathrm{p}<0.05$; \#\#: $<<0.001$, day

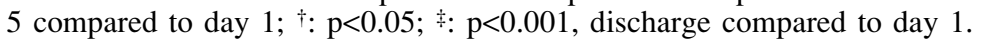


10 patients were still hypermetabolic at discharge. The day after admission, REE in the hypermetabolic patients at discharge was also significantly higher than in the normometabolic patients at discharge $(130 \pm 12$ versus $124 \pm 12 \%$, respectively, $\mathrm{p}<0.05)$, but did not decrease significantly during hospitalization. The hypermetabolic group at discharge was furthermore characterized by a significantly lower BMI $(20.9 \pm 2.8$ versus $24.7 \pm 2.5$ $\mathrm{kg} \cdot \mathrm{m}^{-2}$, respectively, $\left.\mathrm{p}<0.05\right)$. Prevalence of bronchial infection between the subgroups of hyper- (7 out of 10) and (8 out of 13) normometabolic patients at discharge, was not different.

\section{Energy intake compared to REE (and estimated DIT)}

During the first days after admission, a negative energy balance was seen. Energy intake (including intravenous glucose) the day after admission, expressed as percentage of REE and DIT, amounted to $68 \pm 28 \%$. In the subgroup of patients in whom a daily REE measurement was performed, it was shown that the negative balance quickly improved from $69 \pm 32 \%$ on day 1 , and $109 \pm 24 \%$ on day 2 , to $136 \pm 18 \%$ on day 4 , further increasing to $145 \pm 24 \%$ at discharge.

\section{Body composition}

No significant weight change was seen during the hospitalization period. Mean body weight was $63.4 \pm 12$ $\mathrm{kg}$ on admission and $62.9 \pm 11 \mathrm{~kg}$ at discharge. FFM did not change either in this period (42.9 \pm 7.8 and $43.2 \pm 7.5$ $\mathrm{kg}$, respectively). Furthermore, no significant change in the ratio between the resistance of intracellular and extracellular water was detected $(2.1 \pm 0.4$ and $2.2 \pm 0.5$, respectively).

\section{Disease symptoms}

Figure 2 displays the VAS scores of those disease symptoms that changed significantly during hospitalization. Symptoms that did not change were "bloating", "nausea", "vomiting", "difficulties with chewing and swal-

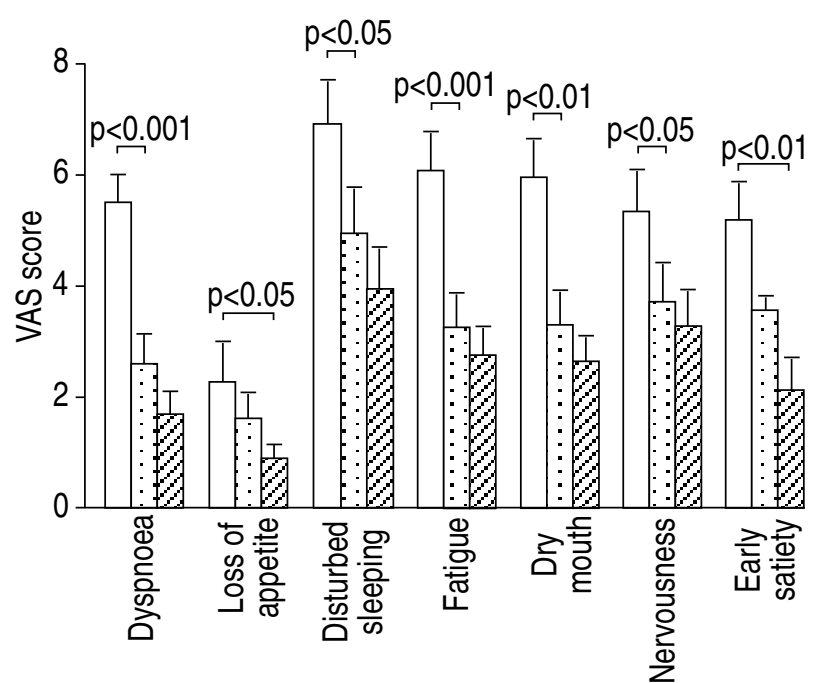

Fig. 2. - Disease symptoms (VAS scores) on admission ( $\square$ ), at day 5 ( $\square$ ) and at discharge from the hospital ( $\square$ ). Results are mean \pm SEM. lowing", "obstipation" and "diarrhoea". On day 5, most symptoms had improved significantly compared to admission, except for the symptoms "dyspnoea while eating", "loss of appetite" and "early satiety". At discharge, the score of these three symptoms was also significantly improved. A significant relationship $(\mathrm{r}=0.52, \mathrm{p}=0.004)$ between the changes in REE and the changes in dyspnoea at rest was observed (fig. 3).

\section{Follow-up consultation}

All patients were asked for a voluntary follow-up consultation 3 months after discharge from the hospital. A minority of the group (43\%) responded. Although the follow-up group tended to have a better lung function and weighed more than the patients that were not followed after 3 months, no significant difference in baseline characteristics was found between these subgroups (table 1). Figure 4 shows the course of dietary intake, using the diet history method, of the follow-up patients. The pattern during hospitalization was comparable with the total group. Three months after discharge, dietary intake was similar to habitual dietary intake $(8,512 \pm 2,290$ and $8,415 \pm 2,600 \mathrm{~kJ} \cdot$ day $^{-1}$ respectively). REE also showed a similar decrease during hospitalization, as was seen in the total group (from 6,931 $\pm 1,248(121 \pm 8 \%)$ to

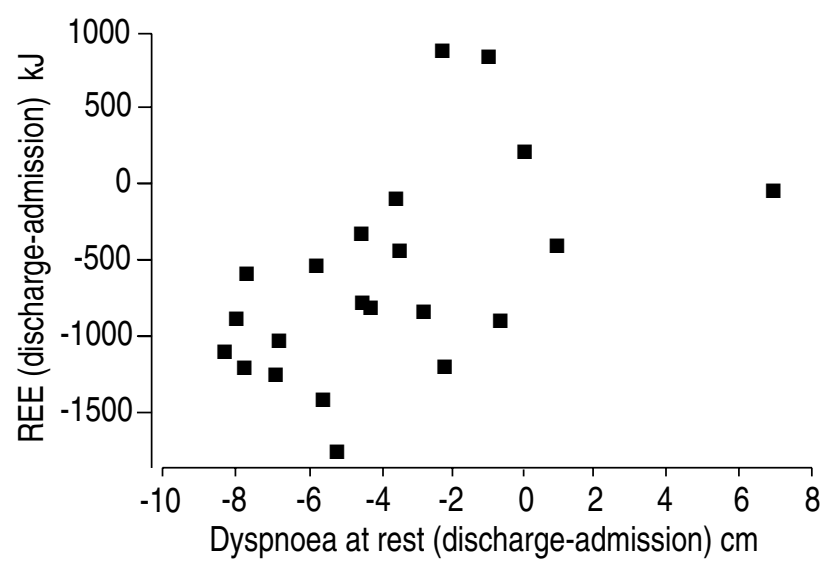

Fig. 3. - Significant relationship between the changes in resting energy expenditure (REE) and dyspnoea sensation during the total hospitalization period $(\mathrm{r}=0.52, \mathrm{p}=0.004)$.

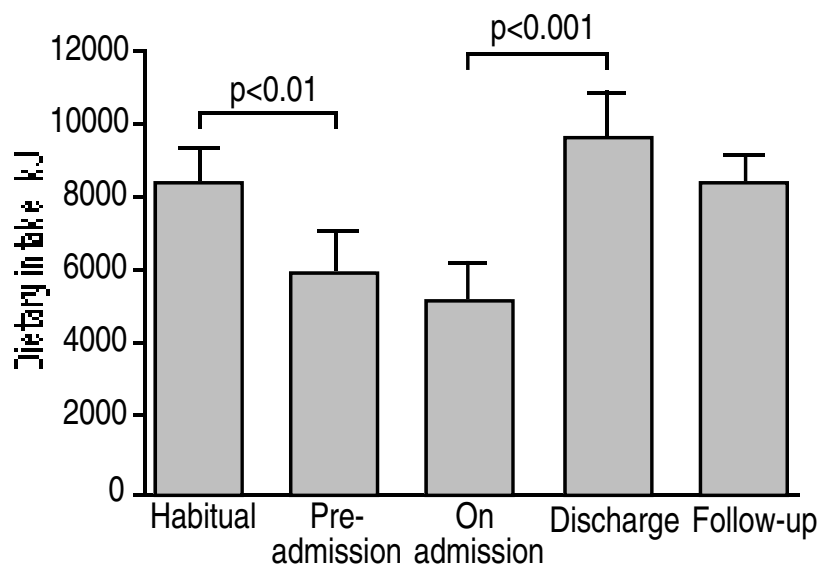

Fig. 4. - Course of dietary intake in 10 patients prior to and during hospitalization for an acute exacerbation and 3 months afterwards in stable clinical condition. Results are mean \pm SEM. 
$\left.6,284 \pm 963 \mathrm{~kJ} \cdot \mathrm{day}^{-1}(110 \pm 9 \%), \mathrm{p}=0.01\right)$. REE amounted to $6,481 \pm 1,633 \mathrm{~kJ} \cdot \mathrm{day}^{-1}(112 \pm 11 \%)$ at follow-up and was not significantly different from the value at discharge. Subsequently energy balance changed from 75 $\pm 35 \%$ on admission to $133 \pm 43 \%$ at discharge, decreasing to $118 \pm 34 \%$ at follow-up. Although body weight did not change either during hospitalization, a significant $(\mathrm{p}<0.05)$ mean (SD) increase in body weight of $1.6(2.1)$ $\mathrm{kg}$ was seen at follow-up. No significant changes were detected in the ratio between intracellular and extracellular water. Furthermore, no clear changes were observed in symptomatology since discharge from the hospital.

\section{Discussion}

Nutritional depletion is a common but possibly reversible problem in patients with COPD. From a therapeutic perspective, it is important to know the course of and contributing factors to weight loss. It is still unclear whether weight loss progresses gradually in patients who are otherwise in a stable clinical condition, or if it follows a stepwise pattern related to acute disease exacerbations. At present, only anecdotal reports have addressed this issue. In the present study, therefore, we assessed the nutritional and metabolic profile of a group of COPD patients suffering from an acute disease exacerbation, on admission to, during the treatment period in, and at discharge from the hospital. In a subgroup of patients, this profile was additionally studied 3 months afterwards in a stable clinical condition.

Several studies of clinically stable patients showed that dietary intake was equivalent to, or exceeded, estimated daily requirements $[7,8]$. In the present study the majority of patients, however, reported a decreased appetite prior to, and a very low dietary intake during, the first 3 days of hospitalization for an acute exacerbation. Thereafter, dietary intake improved quickly during the remaining hospital period. Based on the course of the symptoms VAS scores, multiple factors appear to be related to changes in dietary intake. Taking also the baseline values into consideration, it is hypothesized that it was not so much a decreased appetite, but more the "inability" to eat more due to dyspnoea and fatigue that was related to the very low intake in the first days after admission. In qualitative terms, protein intake was low prior to and during the first days of hospitalization, restored thereafter but remained rather low in order to optimize protein synthesis. Furthermore, it is of interest to note that a low appetite and a decreased dietary intake were reflected in a very low fat intake, which could be related to the early feeling of satiety during these days. This spontaneous response in macronutrient intake is in contrast to a long-held but not yet scientifically confirmed belief that COPD patients would benefit from a high fat, low carbohydrate meal, particularly during acute metabolic stress. When comparing the diet histories prior to admission, at discharge and at the follow-up consultation, the data clearly indicate that at discharge, dietary intake was significantly higher than habitual intake. This could be a compensation related to improvement of symptoms such as dyspnoea, appetite and fatigue, possibly related to reduced resting oxygen consumption and related ventilation and/or inflammation. Another suggested explanation could be an appetite-stimulating effect of high-dosage corticosteroid treatment. Remarkably, energy intake was highest during the tapering-off phase of parenteral corticosteroid treatment.

Several studies measured REE in clinically stable COPD patients with standard methods of indirect calorimetry and found an average increase in REE of 10-20\% higher than predicted from age, weight, height and gender using the Harris and Benedict equations [9, 10]. Limited data are available on the course of REE during an exacerbation. Expressed as percentage of predicted values, REE was enhanced in all patients on admission to the hospital and decreased gradually towards the end of the hospitalization period.

Several factors could contribute to a temporary (further) increase in metabolic rate during an exacerbation. An increased oxygen cost of ventilation related to an increase in elastic and resistive work of breathing, metabolic effects of theophyllines [19] and $\beta_{2}$-agonists [20], or a systemic inflammatory response [21]. The oxygen cost of ventilation was not measured in the present study. The significant relationship between changes in REE and changes in the VAS score for dyspnoea at rest, however, provides indirect evidence for a contribution of the oxygen cost of ventilation to REE during an acute exacerbation. Recently, VANDERHOVEN-AUGUSTIN et al. [22] investigated, in a group of patients hospitalized for an acute exacerbation, the influence of theophylline on REE and found no relationship between (changes in) REE and (changes in) theophylline dose or plasma theophylline levels. Since $\beta_{2}$-agonists are commonly given as part of the pharmacological therapy during an acute exacerbation, CREUTZBERG et al. [23] studied, as part of the present study, the acute effects of $5 \mathrm{mg}$ salbutamol given by a handheld nebulizer containing $1 \mathrm{~mL}$ salbutamol hemisulphate $0.5 \%$ and $1 \mathrm{~mL}$ sodium chloride $0.9 \%$ on REE in COPD patients recovering from an acute exacerbation. Mean REE was raised by $4.2 \%$ up to $45 \mathrm{~min}$ after salbutamol administration, but was not significantly different from a healthy age-matched control group. Using the same dose, BURDET et al. [24] even found a slightly greater thermogenic effect of salbutamol in clinically stable COPD patients, which lasted for several hours. Since patients received both salbutamol by nebulizer and by inhalation during their hospitalization period, we were not able to calculate an average daily dose for subsequent comparison with REE. Two studies have recently reported a significantly enhanced level of tumour necrosis factor $\alpha$ (TNF $\alpha)$ in plasma of weight-losing COPD patients [25, 26]. Acute administration of TNF $\alpha$ in men causes an increase in acute-phase proteins, provokes an elevation of REE, promotes proteolysis and lipolysis and causes anorexia [27]. In clinically stable COPD patients with elevated REE and depletion of FFM, Schols et al. [21] reported increased serum levels of acute phase reactant proteins and soluble tumour necrosis factor (sTNF) receptors suggestive of a relationship between metabolic derangements and a systemic inflammatory response in a subset of COPD patients. Further research is needed to investigate if the relationship between metabolic derangements and inflammation involves a sustained systemic effect of acute inflammatory exacerbations or merely reflects a chronic inflammatory state. 
In this group of mostly bed-rested or sedentary patients, it is conceivable to assume that the energy expenditure of activities is not very high and that the other components (REE and DIT) are a good estimate of total daily energy expenditure. Several studies have shown that DIT is normal in patients with COPD, amounting to approximately $10 \%$ of dietary intake. Analysis of the balance between REE and dietary intake revealed a negative balance on admission which soon restored to normal. Further evidence for a temporary state of negative energy balance was seen in the changes in respiratory quotient from close to 0.7 to 0.8 . In view of the sensibility of the bioelectrical impedance spectroscopy measurement and the duration of hospitalization, the energy imbalance was probably too short to be reflected in body weight and body composition data. The improvement in energy balance was accompanied by a significant improvement in symptoms such as dyspnoea and fatigue. These results imply that an (acute) disease exacerbation can indeed temporarily affect both dietary intake and REE in patients with COPD, but that if a patient responds adequately to the medical treatment, aggressive nutritional support is not indicated in a temporarily unstable clinical condition.

In qualitative terms, our data indicate that protein intake should be increased $\left(1.5 \mathrm{~g} \cdot \mathrm{kg}^{-1} \cdot \mathrm{day}^{-1}\right)$ in order to provide optimal conditions from a nutritional point of view, for protein synthesis in the recovery period. Despite insignificant changes in body weight during hospitalization, improved body weight in the subgroup of patients that were studied 3 months afterwards, suggests the presence of a pre-existing period of energy imbalance in association with the acute exacerbation. To provide more insight in this period, dietary consultation and metabolic evaluation of patients with chronic obstructive pulmonary disease, suffering from an acute exacerbation should include a (retrospective) evaluation of the period prior to hospitalization and be expanded from the in-hospital period to the out-patient recovery period immediately afterwards. The conclusions of this study apply only to patients with acute exacerbation of moderate severity and further studies are needed in patients with severe respiratory failure, especially those requiring mechanical ventilation.

\section{References}

1. Engelen MPKJ, Schols AMWJ, Baken WC, Wesseling GJ, Wouters EFM. Nutritional depletion in relation to respiratory and peripheral skeletal muscle function in an out-patient population with chronic obstructive pulmonary disease. Eur Respir J 1994; 7: 1793-1797.

2. Driver AG, McAlevy MT, Smith JL. Nutritional assessment of patients with chronic obstructive pulmonary disease and acute respiratory failure. Chest 1982; 82: 568-571.

3. Rochester DF, Braun NMT. Determinants of maximal inspiratory pressure in chronic obstructive pulmonary disease. Am Rev Respir Dis 1985; 132: 42-47.

4. Schols AMWJ, Mostert R, Soeters PB, Wouters EFM. Body composition and exercise performance in chronic obstructive pulmonary disease. Thorax 1991; 46: 695-699.

5. Wilson DO, Rogers RM, Wright E, et al. Body weight in chronic obstructive pulmonary disease. Am Rev Respir Dis 1989; 139: 1435-1438.
6. Breslin EH. Dyspnea-limited response in chronic obstructive pulmonary disease: reduced unsupported arm activities. Rehabilitation Nursing 1992; 17: 12-20.

7. Hunter AMB, Carey MA, Larsh HW. The nutritional status of patients with chronic obstructive pulmonary disease. Am Rev Respir Dis 1981; 124: 376-381.

8. Schols AMWJ, Soeters PB, Saris WHM, Wouters EFM. Energy balance in patients with chronic obstructive pulmonary disease. Am Rev Respir Dis 1991; 143: 1248-1252.

9. Goldstein S, Askanazi J, Weissman C, Thomashow B. Kinney J. Energy expenditure in patients with chronic obstructive pulmonary disease. Chest 1987; 91: 222-224.

10. Schols AMWJ, Fredrix EWHM, Soeters PB, Westerterp KP, Wouters EFM. Resting energy expenditure in patients with chronic obstructive pulmonary disease. Am J Clin Nutr 1991; 54: 983-987.

11. ATS. Standards for the diagnosis and care of patients with chronic obstructive pulmonary disease (COPD) and asthma. Am Rev Respir Dis 1987; 134: 239-243.

12. Black G. A review of validations of dietary assessment methods. Am J Epidemiology 1982; 115: 492-505.

13. NEVO tabel. Stichting Nederlands Voedingsstoffenbestand. s'Gravenhage: Voorlichtingsbureau voor de voeding, 1986.

14. Schols AMWJ, Schoffelen P, Ceulemans H, et al. Measurement of resting energy expenditure in patients with COPD in a clinical setting. JPEN 1992; 16: 364-368.

15. Jenin P, Lenoir J, Roullet C, Thomasset AL, Ducrot H. Determination of body fluid compartments by electrical impedance measurements. Aviat Space Environ Med 1975; 46(2): 152-155.

16. Cole KS, Cole RH. Dispersion and adsorption in dielectrics. J Chem Rev 1941; 9: 341-352.

17. SPSS for Windows. MJ Norusis/SPSS Inc, Chicago 1993.

18. Harris JA, Benedict EG. A Biometric Study of Basal Metabolism. Wahington, USA, Carnegie Institution of Washington, 1919.

19. Dash A, Agrawal A, Venkat N, Moxham J, Ponte J. Effect of oral theophylline on resting energy expenditure in normal volunteers. Thorax 1994; 49: 1116-1120.

20. Amoroso P, Wilson SR, Moxham J, Ponte J. Acute effects of inhaled salbutamol on the metabolic rate of normal subjects. Thorax 1993; 43: 882-885.

21. Schols AMWJ, Buurman WA, Staal-v/d Brekel AJ, Dentener MA, Wouters EFM. Evidence for a relation between metabolic derangements and elevated inflammatory mediators in a subset of patients with chronic obstructive pulmonary disease. Thorax 1996; 51: 819824.

22. Vanderhoven-Augustin IML, Schols AMWJ, Smeets HJM, Wouters EFM. The influence of a disease exacerbation of COPD on metabolism and lung function. Eur Respir J 1996; 9: 123s.

23. Creutzberg E, Schols AMWJ, Wesseling GJ, Wouters EFM. Acute effects of inhaled salbutamol on lung function and energy metabolism in COPD patients and normal subjects. Eur Respir J 1994; 7: Suppl. 18, 466s.

24. Burdet L, de Muralt B, Schutz Y, Fitting J-W. Thermogenic effect of bronchodilators in patients with chronic obstructive pulmonary disease. Thorax 1997; 52: 130-135.

25. Di Francia M, Barbier D, Mege JL, Orehek J. Tumor necrosis factor alpha levels and weight loss in chronic obstructive pulmonary disease. Am J Respir Crit Care Med 1994; 150: 1453-1455.

26. deGodoy I, Calhoun WJ, Donahoe M, Mancino J, Rogers RM. Elevated TNF- $\alpha$ production by peripheral blood monocytes of weight losing COPD patients. Am J Respir Crit Care Med 1996; 153: 633-637.

27. Fong Y, Moldawer LL, Marano M, et al. Cachectin/TNF or IL-1 $\alpha$ induces cachexia with redistribution of body proteins. Am J Physiol 1989; 25: R-659-665. 